\title{
MAIN CONTRADICTION OF RELATIONS AT CONSUMER MARKETS AND WAYS OF ITS OVERCOMING
}

\section{Khyzhniak V. O.}

\section{INTRODUCTION}

Adequate representation of inward nature of economic contradictions is only one of the tasks of the economics. As the final result the most probable ways of optimal settlement of existing economic contradictions shall be found on the basis of consensus in parties' interests. But when the interests of economic entities become directly antagonistic the task of the science is to develop proposals, measures and specific mechanisms of their practical settlement on the basis of overcoming a confrontational component of the existing contradictions.

Among urgent problems of the current social and economic development of Ukraine one of the most acute issues is the safety of end-consumer goods for health of population. Its resolving in practice not only will mean the increased quality of life on the basis of implementation of the European high standards but also will affect the qualitative characteristics of social rehabilitation and assurance of social stability and national security.

The above-mentioned is directly affected by solutions that shall be found for the wide range of tasks. A strategic problem is that the state's social and economic policy shall be directed on undermining the base of antisocial interests and motivations which provoke confrontational intensification of the main contradiction of relations between consumer marketers. It is means the removal of any opportunities of formation and implementation of incentive motivations for businesses to maximize their profits by socially dangerous violations of necessary safety regulations or standards applied at the market of vital goods (first of all, food products, beverages and goods for children) that is all things which directly affect the state of health, duration of life and reproductive abilities of people. Finally, all this is one of the main factors which induce the large-scale depopulation of Ukraine and as such requires the government policy directed on introducing and ensuring an effective and functional, multilevel and developed system of mechanisms and measures that guarantee the compliance with the established standard consumer rights and are directed on enhancing economic, legal and socially ethical responsibility of businesses for safety of produced and marketed consumer goods. 


\section{Review of research studies and publications}

It should be noted that various aspects of research studies of essence, roles, tasks and features or forms of manifestation of protection of consumer rights on safety consumption by population have been examined in works of known foreign (P. Drucker ${ }^{1}$, P. Kotler ${ }^{2}$, R. Hirst ${ }^{3}$, J.-J. Lambin ${ }^{4}$, G. Cross ${ }^{5}$, P. Stearns ${ }^{6}$ and others) and native (O. Yazvinska ${ }^{7}$, S. Gerasimova ${ }^{8}$, L. Halat ${ }^{9}$, T. Horodets'ka ${ }^{10}$, T. Kahal ${ }^{11}$, T. Kysil'ova ${ }^{12}$, L. Ivanenko, O. Dzera ${ }^{13}$, A. Mazaraki, L Nikolaieva, N. Prytuls'ka, L. Ivanenko ${ }^{14}$, V. Seleznev ${ }^{15}$, V. Martsyn ${ }^{16}$ and others) researchers and economists.

1 Drucker P.F. Management. Tasks. Responsibilities. Practices. New York: Harper \& Row, 1974. -839 pp.

${ }^{2}$ Kotler P. What consumerism means for marketers // Harvard Business Review, 50(3). 1972. - May-June. - P. 48-57; Kotler P. Basis of marketing. - M., 1991.

3 The consumer society / R.C. Hirst, R.W. Duncan - London: Tavistock Publication, 1977. $-269 \mathrm{pp}$.

${ }^{4}$ Lambin J.-J. Marketing strategique et operationnel: Du marketing a rorientationmarche / J.-J. Lambin, R. Chumpitaz, Ch. Moerloose. - Paris: Dunod, 2005. - 718 pp.

${ }^{5}$ Cross G. An All-Consuming Century: Why Commercialism Won in Modern America. New York: Columbia University Press, 2002. - 256 pp.

${ }^{6}$ Stearns P.N. Consumerism in World History: The Global Transformation of Desire. New York: Routledge, 2001. - 160 pp.

${ }^{7}$ Yazvinska O.M. History of consumerism: Work-book $-2^{\text {nd }}$ rev. and corr. ed. - K.: Kyiv Nat. Comm. and Econom. University, 2003. (in Ukrainian)

${ }^{8}$ Gerasimova S.V. Generalization of approaches to determination of consumerism as an economic category // Actual problems of economics. - 2005. - No. 12. - P. 76-79. (in Ukrainian)

${ }^{9}$ Halat L.M. Problems of protection of consumer rights: the Ukrainian realia // Tauric Scientific Bulletin - Kherson, 1998. - Issue 8. - P. 133-140. (in Ukrainian)

${ }^{10}$ Horodets'ka T.N. Economic and legal mechanism of protection of consumer rights // Social priorities in the transition economy: Coll. of sci. and research articles - Kh., 1999. P. 194-198. (in Ukrainian)

${ }^{11}$ Kahal T. For consumers - reliable legal guarantees // Viche.1999. - No. 2. - P. 116-124. (in Ukrainian)

${ }^{12}$ Kysil'ova T.M. Activities of Derzhstandart of Ukraine in the field of protection of the Ukrainian consumer rights. Struggle with violations in the field of production and trade // For the Government of Ukraine, President, legislation and executive authorities: Analytic developments, proposals of research and pract. workers: Coll. - K., 1999. - Vol. 12. P. 552-557. (in Ukrainian)

${ }^{13}$ Ivanenko L.M., Dzera O.V. Peculiarities of indemnification of losses inflicted on buyers due to acquisition of low-grade goods // Small business and management in Ukraine (public and private principles): Coll of sci. and res. art. K., 1997. - P. 195-202. (in Ukrainian)

${ }^{14}$ Protection of consumer rights: social and legal aspect / Kyiv National Commercial and Economic University; A.A. Mazaraki, O.M. Yazvinska, L.V. Nikolaieva et al. - K.: KNTEU, 2002. - 311 p. (in Ukrainian)

${ }^{15}$ Seleznev V.V. How should your consumer rights be defended? - Kh.: Odyssey, 2005. 416 p. (in Russian)

${ }^{16}$ Martsyn V. Consumer is a central person in market relations // Economy of Ukraine. 1996. - No. 3. - P. 83-85. (in Ukrainian) 
The researchers showed great consideration to a general qualitative estimation of the consumerism as a systemic social phenomenon and an economic mechanism of protection of consumer rights. The researchers also conducted solid studies of the history of development of consumerism and its structural components in various countries of the world in the context of the examination and settlement of wide range of complex problems related to the protection of consumer rights and interests in Ukraine and in the world.

At the same time a wide range of problems remains unsolved. First of all it concerns profound scientific understanding the causes that give rise to the actually existing polarity of motivations and interests of consumer marketers and, under certain circumstances, result in the emergence of antagonistic features of existing economic contradictions during their interactions.

The main factors that intensify the generation and growth of actual risks for the population due to production and distribution of goods which are dangerous for human health and life, first of all, the goods of food groups.

Also there is a necessity to develop and implement the effective business and institutional measures and mechanisms for overcoming the confrontational and dangerous contradictions of consumer marketers' interests on the basis of the fullest use of the world experience, objective appraisal of the state of affairs in the domestic market, the fullest consideration of interests of the population and enhancement of social, economic and legal liabilities of businesses.

Therefore the goal of this article is a justification of theoretical and methodological as well practical and applied measures for overcoming the confrontational nature of the main contradiction of consumer marketers' interests in the way to implementation of the policy of social protection and enhancement of efficiency of the mechanisms of assurance of the consumer rights, first of all, the rights for goods and services that are safe for health and life.

\section{Exposition of main content}

By signing the Agreement of Association between Ukraine, as one Party, and the European Union and its member-states as the other Parties (that was ratified by the Verkhovna Rada of Ukraine in September 2014) our state has undertaken liabilities to ensure a high level of protection of the consumer rights and attain the required compatibility of the systems of consumer rights protection in Ukraine and the EU. First of all, it concerns to implementation of the social and economic policy of introduction of high standards of business responsibility (which are currently in force in the EU) into the consumer domain.

Alongside with this problem the important task of the state economic policy is a formation of the most favorable conditions for liberalization of 
business activities. Nevertheless, it should be admitted that the emphases and priorities used in the process of implementation of the current economic policy with regard to simplification of business environment are not always based on the principles of compliance with the requirements for maintaining the adequate safety of consumption by the population. Today this becomes apparent as the neglect of increased threats that really exist in the domain of end-consumption in performing the measures for simplification of business environment, first of all, the existence of criminal actions from the part of businessmen during production and distribution of goods that are unsafe for the health of population, (primarily food groups).

Under conditions of market relations the high consumer-related properties is a base of products and services competitiveness on both domestic and external markets and the guaranteed consumption of qualitative goods (the benefits of life) rises the level of living standards and ensures satisfaction of their various needs that are the base of comprehensive and harmonic development of personality and extended reproduction of human capital. Just therefore the Constitution of Ukraine (art. 50) guarantees the protection of consumer rights, in particular, the rights of citizens for environment that is safe for health and life, and the free access to information about the state of environment, quality of food products and household goods and the right for its distribution.

\section{Causes of the confrontational intensification of the main contradiction of the consumer market}

The main contradiction of relations at the consumer market not only occurs due to discrepancy of interests but is a consequence of the absolute antagonism of interests of principal marketers (businessmen, producers or distributors, on the one part and population, end-consumers of the benefits for life on the other part) at all. That is the essence of the contradiction is an absolute difference in the subject matters of incentive motivations of capitalist market entities as the producers and distributors strive for maximum personal profits but the population strives for satisfaction of personal needs by consumption of goods and services that are safe for health and life.

A main and very dangerous feature of the process of marketing of goods for life is a potential transformation of the above-mentioned contradiction into antagonism as a result of its intensification under possible conditions of the absolute breach of parity and equivalency of relations between market entities due to irresponsible, uncontrolled and non-punishable prevalence of private interests on the part of businesses.

This phenomenon that is founded on the deep-laid and unrestricted by high moral principles aspiration of the capital for maximum profits was 
explained by the British journalist Danning T.J. in his article 'Trades' unions and strikes' published in London as long ago as in 1860. As far back as at the early stage of the development of capitalist mode of production the author affirmed that 'the capital is afraid of lack of profits ... if the profit is sufficient the capital becomes audacious ..., at 50 per cent it is positively ready to break its neck, at 100 per cent it violates all human laws, at 300 per cent there is no such a crime for which it will not venture even under penalty of hanging, ${ }^{17}$.

The historical experience of development of the countries with the civilized market economy indicates irrefutably that when the state is inactive and the institutions of civil society are weak the business, in chase of superprofits, constantly violates the ethics of market relations, first of all by producing and proposing low-grade and unhealthy consumer products. Such a state of affairs existed even in the countries with the advanced market economy at the beginning of the second half of the twentieth century at the latest.

Businessmen realize their aspirations for higher profits not always by legitimate means and very often they can act contrary or even to the detriment of consumer's needs and interests. Just for this reason the state and the civil society shall establish standing and effective systems for accounting and controlling production and mediatory market activities and ensure the implementation of a social and economic policy directed on formation and putting in order the corresponding mechanisms that strictly support economic and legal feedback in relations between market entities. That is such mechanisms whose actions ensure the significant influence of a wide circle of consumers on the motivational behavior of businessmenmanufacturers to guarantee the proper quality of sold goods and services.

\section{Development of the state policy and strengthening the effect of the mechanism of social and economic protection in the way of overcoming the main contradiction of relations on the consumer market}

Under conditions of present-day changes that take place at the global level the state's capability to ensure the actual effectiveness of the its own economic, social-economic or social policy comes up to the higher level of urgency. The state policy shall result in the fullest achievement of the specified both strategic and tactical goals. However, the concept of policy effectiveness shall not be restricted by the capability to implement adopted decisions by the state machinery that performs specific tasks of routine nature. In opinion of Ya. Zhalylo the prerequisites of efficiency of the state policy shall ensure the state's capability to perform tasks designed to affect

\footnotetext{
${ }^{17}$ Dunning, T. J. Trades’ Unions and strikes. London, «Quarterly Reviewer», 1860. - P. 35-36.
} 
social and economic processes, maintain certain priorities and neutralize potential risks with the use of levers of the market economy ${ }^{18}$.

Dialectic of life insistently indicates that the two components of the economic and social-economic policy shall be strictly and optimally implemented: on the one hand, the liberalization of business environment to contribute to simplification of requirements for conducting business activities, on the other hand, the continuous improvement of measures and mechanisms that strengthen business responsibility for the environment that ensures the real safety of end-consumption for the population.

The functional assignment of the social and economic policy is political coordination and regulation of a wide spectrum of social and economic relations which the state carries out on the principles and in the interests of all people of the country or in the interests of social groups and classes that rule and dominate in the state. In substance, the state's social and economic policy is a totality of scientifically formulated ideas, provisions and conceptual approaches (of both the long-term strategic and short-term tactical nature) which combine with a system of specific actions and mechanisms and with the use of which the conscious and competent regulation of social and economic processes is practically performed with due account of mechanisms of market and natural self-regulation.

The state policy of social and economic protection of consumer rights is an important component of the social and economic policy. Realization of this important part of the social and economic policy is carried out by means of functioning (with various levels of efficiency) of the mechanism of social and economic protection of consumer rights.

In substance and by implication this mechanism is a complex system of interrelated economic, social, legal, organizational, business, organizational and social, social and legal, ethical and moral measures, actions, levers, tools, economic and legal sanctions, incentives and social motivations which are used by the state to overcome the confrontational nature of the main contradiction of relations on the consumer market. This task is fulfilled at various institutional levels (an enterprise, firm, civil society) and ensures the implementation of the legally established rights of end-consumers to qualitative and safe satisfaction of life needs that are required not only for the simple but also for expanded human reproduction both on the familyindividual and on the social levels.

\footnotetext{
${ }^{18}$ Agreement of Association between Ukraine and the EU. Section V. Chapter 20 «Economic and sectoral cooperation» P.5 [Electronic resource]. - Access mode:. http://zakon2.rada.gov.ua/rada/show/984_011
} 
The mechanism of social and economic protection of consumer rights is multifunctional and systemic-structured and comprises the components shown in a scheme (Fig. 1).

The mechanism of ensuring quality and safety of end-consumer goods is an internal-systemic component of the general mechanism of social and economic protection of consumer rights.

This internal-systemic mechanism is also a multifunctional (with a various level of efficiency) system of actions, tools and sanctions which are used to form motivational prerequisites and exert direct and incentive influence on manufacturers and market agents by means of securing the application of corresponding quality regulations and standards of products, procedural measures of their certification, supervision and monitoring production processes, compliance with the requirements for licensing of business activities and securing the corresponding terms of marketing of these products to end-consumers.

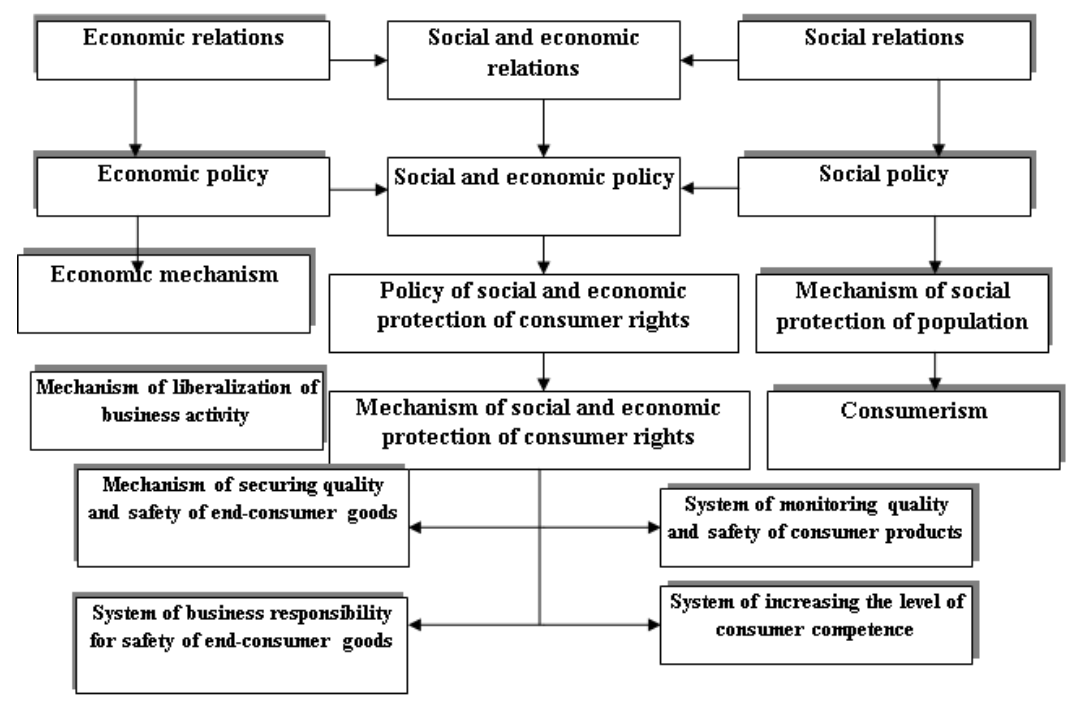

Fig. 1. Scheme of systemic interconnections and interactions of the social and economic policy the mechanism of social and economic protection and its systemic components (author's design)

Mechanism of ensuring quality and safety of end-consumer goods at the individual and social levels shall secure the realization of the guaranteed right of people to consume qualitative benefits and services which they get 
in the process of market exchange (from manufacturers, specialized sellers and private persons who have right to produce and sell consumer goods). The mechanism acts on the principles of binary combination of two organizational components: the state and the civil society. It gives an opportunity to overcome the main contradiction of relations on the consumer market.

The following systemic components are also important factors for overcoming the antagonistic nature of the contradiction: 1) a system of monitoring the quality and safety of consumer products; 2) a system of business responsibility for safety of end-consumer goods; 3) a system of increasing the level of consumer competence of the population. The content of these systemic components requires special consideration.

\section{Basic stages of cardinal transformation of the state policy of protection of consumer rights in Ukraine}

Three basic periods that characterize the priorities of the state policy and, accordingly, the actual state of protection of consumer rights in Ukraine may be singled out.

1. Period 1991-2001 may be considered as rather contradictory. On the one hand, just in the same period the state promotes the accelerated formation of a branched regulatory and legal framework for protection of consumer rights in the market of goods and services in the country's legislation field. Today the system comprises eight laws and thirteen bylaws $^{19}$. Therefore, at first sight it seems that this legal system shall function rather reliably and protect the interests of end-consumers efficiently. On the other hand, just in the same period a significant institutional weakening of the control over low-grade and unsafe goods took place. First of all, this situation occurs due to unsystematic demolishing of the old control system and inadequate functioning of a new control system given threats of existed large-scale corruption.

In this period a rather branched and sufficiently effective state system for controlling low-grade goods existed in Ukraine. First of all, this system comprises the powerful service of sanitary and epidemiological control of the Ministry of Health as well as the products certification bodies of Derzhstandart and other ministries and departments that have not been liquidated earlier and the control bodies of Derzhspozhyvzahyst. In particular, the system of state certification of Ukraine comprised 138

\footnotetext{
${ }^{19}$ Mandybura V.O., Khyzhniak V.O. Problems of ensuring the adequate economic responsibility of business for violations of consumer rights // Scientific transactions of the Institute of Legislation of the Verkhovna Rada of Ukraine. - 2017.- No. 5. - P. 74-90 (in Ukrainian).
} 
accredited bodies, 17 ministries and departments. About 680 test laboratories for 32 product types functioned in this system.

Just during the first stage when the monitoring and, in particular, laboratory and research base was reducing the most dangerous threats for consumers were established and up to date these threats remain topical.

The production of bakery products became unsafe for domestic consumers due to the use of various food synthetic additives which had not been approved by the MOH of Ukraine. In particular, there were cases when metaphos, a highly toxic substance, was detected in bread and metaphos decomposition products were detected in raw materials.

The campaign for 'deregulation' of the economy that was started in this period resulted in the state when business entities which had passed the official procedure of registration could start the production of products without the corresponding technical or technological qualification and any normative documents and the legislation in force did not forbid them to do so. This resulted in growth of large-scale violations of consumer rights, in particular, the right to health.

The situation became especially unsafe due to reduced attention paid to proper quality and safety of infant food products. Non-availability of reliable and necessary information about goods and possibility of selling infant food products without certificates of conformity and with elapsed expiration dates were among large-scale violations. As a rule, the quality control of consignments of infant food products supplied in Ukraine under contracts with foreign partners was not comprehensive. In particular, very often the date of production was not indicated on the manufacturer identification label, only the month and year of production. As a result, the identification of a specific consignment of products with the use of the document that confirmed their proper quality became impossible.

Just in this period businessmen began to apply the unsafe for health synthetic additives during production of food products on a large scale.

Color additives (for imparting attractive colors to food products), unsafe ones: E110, E123, E127, E129, E150, E151, E173-175; conserving agents (for prolonging shell lives of food products before consumption), unsafe ones: E210, E212, E216-219, E227, E228; antioxidants (for retarding oxidation, inhibit spoilage of foods, are similar to conserving agents by their action), unsafe ones: E330; E339-341; stabilizers (for maintaining the specified consistency of food products), unsafe ones: E400-403, E450-452; emulsifiers (for maintaining a certain structure of good products, are similar to stabilizers by their action), unsafe ones: E521-523, E541-556, E559, E574-579; flavor intensifiers, unsafe ones: E620-625; 
2. Period 2001-2011 may be considered as the most effective for strengthening the protection of consumer rights, first of all, by raising requirements for quality and safety of food products.

First of all, this period may be considered as the most active time as regard to strengthening the effective checking of manufacturers and market agents for quality of products by the corresponding authorities for protection of consumer rights.

Also some positive moments in the functioning of the state authorities for protection of consumer rights on the market of end-consumer goods and services may be highlighted. These actions were directed on development and active reviewing of interstate standards developed before 1992 that were in force in Ukraine at that time. This work was carried out in accordance with the Program of bringing them in accordance with the Agreement on technical barriers in trade with the World Trade Organization and harmonization with the European model of standardization.

Main directions in implementation of the above Program were as follows:

1) reviewing the interstate standards for compliance with the legislation, interests of the state, consumer needs, levels of development of science and technology, requirements of international and regional standards, position of the Agreement on technical barriers in trade; 2) reviewing the interstate standards and making changes in them or replacing them by the corresponding international or national standards; 3) withdrawing the interstate standards that ceased to be topical, were not used and didn't comply with the current legislation.

The intermediate index of performing the Program for that period was as follows: as on 29.12.2007 4565 national standards that had been harmonized with the international or the European once were in force in Ukraine.

3. Period from 2012 to the present time is a period of significant weakening of the level of protection of consumer rights. The actual practice shows that after the period of the intensified effective checks of goods quality the state authorities for protection of consumer rights abruptly decreased the number of checks in pursuance of the keynote on prevention of corruption and in compliance with the requirement for 'maximum liberalization of business activities'. Therefore the number of recorded cases of criminal violations of consumer rights was reduced accordingly.

However, at the present time the domestic corruption heads all world records ${ }^{20}$ and criminal offences in the field of violations of consumer rights and manifestations of negative consequences of these crimes for the

\footnotetext{
${ }^{20}$ Mandybura V.O. Corruption: institutional essence and mechanisms of overcoming / monograph. - K.: Parliament Publ. House, 2017. - P. 488 (in Ukrainian).
} 
population continue to rise. Even at the official level this situation is considered as extremely unsatisfactory. Thus the Concept of the state policy in the field of protection of consumer rights for the period up to 2020 clearly states that «the consumers in Ukraine are not protected by the state and the law due to the declarative nature of the declared rights and lack of mechanisms of their implementation and recommencement'. The lack of complete system of the state supervision (monitoring) results in creation of competitive advantages for unscrupulous businesses. Thus the domestic consumer market is more risky for consumers and violations of their rights occur on the large scale. Majority of economic entities (manufacturers) lose their competitiveness both inside the country and in the common with the EU market. The spread of unsafe products and low-grade products in the domestic market becomes more dangerous for health and life of the population $^{21}$.

Just therefore the Concept specifies '.. harmonization of the system for protection of consumer rights in Ukraine with the principles, approaches and practices of the EU; protection of the constitutional guarantees of consumption safety and quality ...; improvement of efficiency of the system for protection of consumers against unsafe products which can harm the life, health or property of consumers, the environment including efficiency of the state market supervision' as one of the most important tasks.

\section{Elimination of inadequacies and economic responsibility of business for violation of consumer rights in overcoming the main contradiction}

The important direction of actions for liquidation of antagonistic manifestations of the main contradiction of the consumer market is the improvement of the system of adequate responsibility of business for safety of end-consumer goods, in particular, it concerns the evaluation of real capabilities of the existing regulatory and economic framework to ensure the adequate responsibility of businesses in cases of fraudulent or counterfeited violations of the regulated norms and standards of quality and safety of marketed benefits for life, whose consequences directly affect the health state and duration of life of people.

The basic economic sanctions for particular violations of consumer rights are regulated by Article 23 of the Law of Ukraine «On protection of consumer rights».

The old ways to deceive buyer or customers are as follows: cheating in measuring, weighing, or counting. The modern negative practice includes a

\footnotetext{
${ }^{21}$ Concept of the state policy in the field of protection of consumer rights for the period of up to 2020 approved by the Decree of the Cabinet of Ministers of Ukraine dated March 29, 2017 No/ 217-r. Ukraine [Electronic resource]. - Access mode: zakon.rada.gov.ua/laws/ show/217-2017 (in Ukrainian).
} 
wider spectrum of other 'up-to-date' manifestations of deceptions of consumers. In particular it concerns all such manifestations of fraudulent falsifications of declared consumption quality of marketed low-grade and unsafe for life and health goods, first of all food products and beverages including spirits. The structural analysis of letters-appeals of citizens at the address of Derzhspozhyvstandart (State agency of consumption standards) of Ukraine confirms the above and shows that ' 42 per cent of consumers complain of low-grade or counterfeited goods, first of all food products (meat and milk, bakery, confectionery products, drinking water and spirits and tobacco goods) ${ }^{, 22}$.

It is important to say that the personal aspect of crimes related to the violations of people rights to consume the products which are safe for health and life is characterized by just the deliberate form of incentives by which a business entity is guided when he (or she) commits a crime that defines his (her) guilt. At the same time due to lobbying efforts Article 225 was withdrawn from the Criminal Code of Ukraine. This article provided for strengthening the responsibility for repeated offences that were committed by a person who had been earlier convicted for deceits of buyers or customers and inflicted $a$ penalty at the rate of one hundred to five hundred of the tax-free minimum income of an individual or putting under restraint for the term of up to three years. (Note: is should be said that in the USA the money equivalent of the restraint for three years is a sum of recovery from 10,000 to 50,000 USD. To compare, in Ukraine the above term of restraint corresponds an absolutely scanty and inadequate sum in UAHs that is an equivalent of 325 USD. Given the exchange rate this sum equals 500 taxfree minimum incomes of an individual specified in the national legislation!!!)

All above-mentioned allow us to make a conclusion that the economic responsibility of business for violations of consumer rights, which is defined by the universal measure that is currently in force and equals a certain number of 'the regulatory tax-free minimum income of an individual', may be considered as not only inadequate but pitiful and trifling at all.

The tax-free minimum income of an individual was approved by the legislation at the level of $17 \mathrm{UAH}$ in 1995. Up to the present it was not reviewed at all. But for the period from 01.10.1995 to 01.12.2017 the price inflation index at the consumer market as well as the exchange rate $\mathrm{USD} / \mathrm{UAH}$ increased by more than order. If at the moment of approval of the tax-free minimum the exchange rate USD/UAH used as a basic value was 1.7:1.0, now it exceeds $26: 1$. The above shows that for the 22 year period the

\footnotetext{
${ }^{22}$ Protection of consumer rights in Ukraine [Electronic resource]. - Access mode: www.radiosvoboda.org/a/1984258.html (in Ukrainian).
} 
inflationary depreciation of the purchasing power of hryvnia is 15.3 times and the tax-free minimum itself has decreased from the equivalent level of 10 USD down to a scanty equivalent that now does not exceed 65 cents.

The above-mentioned indicates that as for today all regulatory economic sanctions for manifestations of criminal violations of consumer rights, which are calculated in the regulatory specified number of 'the tax-free minimum income of an individual', are absolutely pitiful and trifling (as it was mentioned earlier) from the economic point of view of an adequacy of the sanctions in force.

First of all, the performed analysis indicates the inadmissibility of further application of the tax-free minimum income of an individual as a regulatory basic value for determination of an economic sanctions volume for criminal violations of consumer rights because their aggregate cost values are scanty under current economic conditions.

The author's proposal to increase adequate economic responsibility of business consists in the necessity of urgent introduction of a new universal regulatory base value into the domestic practice. This value is a scale-fixed cost that is determined on the principles of application of the indices of the income base of the consolidated government budget. The value shall be fixed if expressed in hryvnias and valid within the current year.

A The regulatory base value shall be established by means of implementation of three basic principles:

1) to provide inflatory neutrality of the scale cost value of index by using an objective and high-quality scientifically based method of its determination;

2) to provide social justice that is to eliminate any possibility of further use of existing social and economic norms such as minimum wages, lower income limit, living wages, tax-free minimum incomes of individuals and others;

3) to eliminate lobbying and corporative interests, possibility of their realization in practice by means of selfish - motivated influence both on the process of objective and adequate determination of the value of regulatory base index and barring of its regular reconsideration.

The method of calculation of the regulatory base value provides its determination as one billionth of an average value of the income part of the consolidated budget of Ukraine taken for the three previous years before the year of approval of a budget for the next fiscal year.

Example:

1. If in 1995 the income part of the consolidated budget of Ukraine was 20,689.9 bln UAH; in 1996 - 30,218.7; in 1997 - 28,112.0 bln UAH, then the regulatory base value that should be approved for 1999 shall be 26.3 UAH (not $17 \mathrm{UAH}$ ). 
2. If in 2007 the income part of the consolidated budget of Ukraine was $219,936.5$ bln UAH; in 2008 - 297,893.0; in 2009 - 272,967.0 bln UAH, then the regulatory base value that should be approved for 2011 shall be 263.6 UAH (not 17 UAH).

3. If in 2014 the income part of the consolidated budget of Ukraine was ....... bln UAH; in 2015 - ........ bln UAH; in 2016 - ....... bln UAH, the regulatory base value that should be approved for 2018 shall be established at the level of ....... UAH (not 17 UAH).

The regulatory base value shall be calculated and approved by the Verkhovna Rada of Ukraine every year together with the approval of the budget of Ukraine for the next fiscal year in which this value shall be used.

For the purpose of adaptation of market entities to a new level of the regulatory base value a four (4) year transition period may be provided: during the first year the norm of $25 \%$ of the regulatory base value shall be applied; during the second year $-50 \%$; during the third year $-75 \%$. Beginning from the fourth year the norm of $100 \%$ shall be applied.

Thus, the proposed mechanism can be used for conducting the annual indexation of the regulatory base value for the purpose of complete and unbiased accounting of the dynamics of existing inflatory process and changes in the GDP (growth or drop) and excluding any actual decrease in the cost value of this index down to an inadmissible level.

\section{CONCLUSIONS}

Under conditions of the process of integration with the EU Ukraine undertakes to ensure a high level of protection of consumer rights, first of all, to introduce the high standards of product safety that are currently in force in Europe and to ensure the adequate economic, legal, ethic and moral responsibility of businesses for violations of consumer rights.

Antagonistic contradictions of relations on consumer markets originate as a result of opposite interests of major market entities: on the one hand, businessmen-manufacturers and businessmen-distributors, on the other hand, the population or end-consumers of benefits for life. These contradictions are conditioned by the aspiration of businesses for maximum personal profits for any price, even for the sake of people's interests while the population strive for satisfaction of personal needs in consumption of goods and services that are safe for health and life.

The important political directives of compliance with maximum liberalization of business activities and prevention of corruption shall not be implemented by means of weakening the level of protection of domestic consumer rights and abandoning the monitoring functions of the state. On the national arena the state policy shall be directed at the ceaseless 
implementation of the European integration concept of «the absolute responsibility of manufacturers» for the quality and safety of produced and distributed goods.

On the way to overcoming the main contradiction of relations on consumer markets the mechanism of social and economic protection of consumer rights is instrumental. This mechanism is a complex system of interrelated economic, social, legal, organizational, economic-organizational, social-organizational, social-legal, ethic-moral measures, actions, levers, tools, economic and legal sanctions, incentives and social motivations which are used by the state in overcoming the antagonistic contradiction of relations on consumer markets. The specified task is fulfilled at various institutional levels (an enterprise, firm, civil society) and ensures the implementation of the legally established rights of end-consumers to qualitative and safe satisfaction of life needs that are required not only for the simple but also for expanded human reproduction both on the familyindividual and on the social levels.

Recording under domestic conditions of numerous manifestations of fraudulent falsifications of declared consumer quality in the process of marketing low-grade and unsafe for life and health goods, first of all, food products and beverages including spirits, demands strengthening and irreversibility of legally specified economic sanctions for criminal violations of consumer rights. There is a necessity to reject the practice of determination of the amount of penalty sanctions in terms of the specified number of 'tax-free minimum income of an individual' as from the economic point of view such a penalty is absolutely inadequate, pitiful and trifling as compared with losses inflicted on consumers. Just for this reason the further use of the tax-free minimum income of an individual as a basic cost value for determination of the amount of economic sanctions for criminal violations of consumer rights is inadmissible.

The author's proposal consists in the introduction of a new regulatory base value into practice. This value features inflatory stability as it is a scalefixed cost that is determined on the principles of application of the indices of the income base of the consolidated government budget. The value shall be fixed if expressed in hryvnias and valid within the current year. The bases and content of the method of calculation of the regulatory base value are described in the article.

\section{SUMMARY}

Consumer marketers' motivations and interests causing antagonistic contradictions have been considered. Main factors that lead to increased actual threats to population due to production and distribution of goods which are unsafe for human life and health, in particular, food group, have 
been established. Salient features of the process of formation of the institution of confidence on the basis of interactions between the institutions of consumerism and marketing have been demonstrated by using the countries with advanced market economy as an example. Stages and main indices of the process of implementation of the policy of protection of interests of consumer marketers have been characterized. Dangers of implementation of the policy of business liberalization at the expense of curtailment of mechanisms of consumer right protection and securing irreversible legal and economic liabilities of businesses for quality and safety of end-consumer goods have been confirmed. The ways of settlement of antagonisms at the consumer market by implementation of effective mechanisms of strengthening the adequate responsibility of businesses in cases of criminal or fraudulent violations of consumer rights and noncompliance with the requirements for goods to be safe for human health and life have been demonstrated.

\section{REFERENCES}

1. Drucker P.F. Management. Tasks. Responsibilities. Practices. New York: Harper \& Row, 1974. - 839 pp.

2. Kotler P. What consumerism means for marketers // Harvard Business Review, 50(3). - 1972. - May-June. - P. 48-57; Kotler P. Basis of marketing. - M., 1991.

3. The consumer society / R.C. Hirst, R.W. Duncan - London: Tavistock Publication, 1977. - 269 pp.

4. Lambin J.-J. Marketing strategique et operationnel: Du marketing a rorientationmarche / J.-J. Lambin, R. Chumpitaz, Ch. Moerloose. - Paris: Dunod, 2005. - 718 pp.

5. Cross G. An All-Consuming Century: Why Commercialism Won in Modern America. - New York: Columbia University Press, 2002. - 256 pp.

6. Stearns P.N. Consumerism in World History: The Global Transformation of Desire. - New York: Routledge, 2001. - 160 pp.

7. Yazvinska O.M. History of consumerism: Work-book $-2^{\text {nd }}$ rev. and corr. ed. - K.: Kyiv Nat. Comm. and Econom. University, 2003. (in Ukrainian)

8. Gerasimova S.V. Generalization of approaches to determination of consumerism as an economic category // Actual problems of economics. 2005. - No. 12. - P. 76-79. (in Ukrainian)

9. Halat L.M. Problems of protection of consumer rights: the Ukrainian realia // Tauric Scientific Bulletin - Kherson, 1998. - Issue 8. - P. 133-140. (in Ukrainian) 
10. Horodets'ka T.N. Economic and legal mechanism of protection of consumer rights // Social priorities in the transition economy: Coll. of sci. and research articles - Kh., 1999. - P. 194-198. (in Ukrainian)

11. Kahal T. For consumers - reliable legal guarantees // Viche.1999. No. 2. - P. 116-124. (in Ukrainian)

12. Kysil'ova T.M. Activities of Derzhstandart of Ukraine in the field of protection of the Ukrainian consumer rights. Struggle with violations in the field of production and trade // For the Government of Ukraine, President, legislation and executive authorities: Analytic developments, proposals of research and pract. workers: Coll. - K., 1999. - Vol. 12. - P. 552-557. (in Ukrainian)

13. Ivanenko L.M., Dzera O.V. Peculiarities of indemnification of losses inflicted on buyers due to acquisition of low-grade goods // Small business and management in Ukraine (public and private principles): Coll of sci. and res. art. K., 1997. - P. 195-202. (in Ukrainian)

14. Protection of consumer rights: social and legal aspect / Kyiv National Commercial and Economic University; A.A. Mazaraki, O.M. Yazvinska, L.V. Nikolaieva et al. - K.: KNTEU, 2002. - 311 p. (in Ukrainian)

15. Seleznev V.V. How should your consumer rights be defended? - Kh.: Odyssey, 2005. - 416 p. (in Russian)

16. Martsyn V. Consumer is a central person in market relations // Economy of Ukraine. - 1996. - No. 3. - P. 83-85. (in Ukrainian)

17. Dunning, T. J. Trades' Unions and strikes. London, «Quarterly Reviewer», 1860. - P. 35-36.

18. Agreement of Association between Ukraine and the EU. Section V. Chapter 20 «Economic and sectoral cooperation» [Electronic resource]. Access mode:. http://zakon2.rada.gov.ua/rada/show/984_011

19. Mandybura V.O., Khyzhniak V.O. Problems of ensuring the adequate economic responsibility of business for violations of consumer rights // Scientific transactions of the Institute of Legislation of the Verkhovna Rada of Ukraine. - 2017.- No. 5. - P. 74-90. (in Ukrainian)

20. Mandybura V.O. Corruption: institutional essence and mechanisms of overcoming /monograph. - K.: Parliament Publ. House, 2017. - P. 488. (in Ukrainian)

21. Concept of the state policy in the field of protection of consumer rights for the period of up to 2020 approved by the Decree of the Cabinet of Ministers of Ukraine dated March 29, 2017 No/ 217-r. Ukraine [Electronic resource]. - Access mode: zakon.rada.gov.ua/laws/show/217-2017. (in Ukrainian)

22. Protection of consumer rights in Ukraine [Electronic resource]. Access mode: www.radiosvoboda.org/a/1984258.html. (in Ukrainian) 
23. Mazaraki A. Lahytin V. Domestic market of Ukraine under conditions of unbalances between production and consumption // Scientific journal «Economy of Ukraine». - 2016. - No. 4 (653) - P. 4-18. (in Ukrainian)

24. Consumerism. Search for the Consumer Interest. - New York; London, 1974. - P. 6-7.

25. Chevrolet Corvair 1960-1969 - «Dangerous at any speed» [Electronic resource]. - Access mode: www.drive2.ru/b/2639701.

26. Heiets V.M. Interaction of confidence and development / V.M. Heiets// Scientific journal «Economic theory».- 2002. - No. 3. P. 3-16. (in Ukrainian)

27. Zhalylo Ya. Evolution of effectiveness factors of the state economic policy and institutional crisis in Ukraine /Ya. Zhalylo// Scientific journal «Economic theory». - 2015. - No. 2. - P. 5-18. (in Ukrainian)

28. Reports on performance of Derzhprodspozhyvcluzhba [Electronic resource]. - Access mode: www.consumer.gov.ua / ContentPages / Zviti_Pro_Robotu_Derzhprodspozhivsluzhbi/170. (in Ukrainian)

\section{Information about the author: Khyzhniak V. O., Candidate of Economic Sciences, Director of the State Enterprise} «Research Institute of Building Production named of V.S. Balitsky» 51, Lobanovskyi av., Kyiv, 03110, Ukraine 